УДК

\title{
КОМПАКТНЫЙ СВЕРХШИРОКОПОЛОСНЫЙ ФИЛЬТР НА ОСНОВЕ ТРЕУГОЛЬНЫХ СОГЛАСУЮЩИХ РЕЗОНАТОРОВ
}

\author{
ДХИРЕНДРА КУМАР ${ }^{1}$, АСОК ДЕ ${ }^{2}$ \\ ${ }^{1}$ Технологический институт Махараджа Аграсен, \\ Индия, Дели, Нью-Дели \\ ${ }^{2}$ Нацииональный технологический институт, \\ Индия, Патна
}

\begin{abstract}
Аннотация. В работе предложен компактный сверхширокополосный фильтр. Рабочая полоса фильтра обеспечивается комбинацией фильтра верхних частот и фильтра нижних частот. Фильтр нижних частот, используемый в данной комбинированной структуре, представляет собой треугольный согласующий резонатор, а фильтр верхних частот представляет собой структуру, использующую короткозамкнутые шлейфы. Конечная структура представляет собой компактную конфигурацию сверхширокополосного фильтра. Групповая задержка фильтра является практически неизменной во всей рабочей полосе фильтра. Результаты компьютерного моделирования хорошо согласуются с результатами измерений параметров рассеивания ( $S$-параметров). Достигнута относительная ширина полосы частот 130\%
\end{abstract}

Ключевые слова: полосовой фильтр; сверхширокополосный треугольный согласующий резонатор; фильтр нижних частот; фильтр верхних частот; шлейф линии передачи

\section{1. ВВЕДЕНИЕ}

В 2002 Федеральная комиссия связи FСС (Federal Communications Commission) одобрила коммерческое использование сверхширокополосных устройств UWB (ultra wide band) с рабочим частотным диапазоном 3,1-10,6 ГГц [1]. Для сверхширокополосных устройств относительная ширина полосы частот полосового фильтра используется более чем на $100 \%$. Для достижения такой широкой полосы частот при использовании параллельных резонаторов необходима сильная связь между ними.

Практическая реализация такого фильтра достаточно сложна, т.к. необходимо обеспечить сильную связь, следовательно, очень малое расстояние между конечными резонаторами [2-4]. В литературных источниках упоминаются различные технологии разработки по- лосовых фильтров для применения в сверхширокополосных устройствах [5-13]. Очень большой коэффициент связи может быть достигнут при использовании конструкции копланарного волноводного полосового фильтра [5]. Однако, высокая относительная рабочая полоса частот в данном случае не реализована.

Полосовой фильтр со сверхширокой полосой и практически постоянной групповой задержкой [6] реализован с использованием материала с высокими вносимыми потерями (около 6,7 дБ). Другой фильтр [7] разработан с использованием экранированной многослойной структуры. Ширина щели предложенного встроенного многомодового резонатора делает указанный полосовой фильтр более широкополосным и миниатюрным [8]. Три цифровые связанные (краями) микрополосковые линии 